See discussions, stats, and author profiles for this publication at: https://www.researchgate.net/publication/43050216

\title{
Analysis of constructed wetland performance for irrigation reuse
}

Article in Water Science \& Technology · April 2010

DOI: $10.2166 /$ wst.2010.063 · Source: PubMed

CITATIONS

45

2 authors:

(3)

Helena Marecos do Monte

Instituto Politécnico de Lisboa

44 PUBLICATIONS 800 CITATIONS

SEE PROFILE

Some of the authors of this publication are also working on these related projects:

Project I am retireing. View project

Project Evaluation of wastewater induced bioclogging in geotextiles View project
READS

525

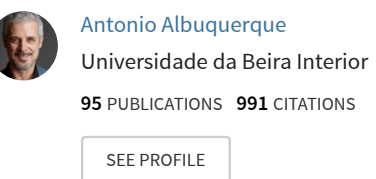




\title{
Analysis of constructed wetland performance for irrigation reuse
}

\author{
Helena Marecos do Monte and António Albuquerque
}

\begin{abstract}
Most of the wastewater treatment systems in small rural communities of the Cova da Beira region (Portugal) consist of constructed wetlands (CW) with horizontal subsurface flow (HSSF). It is believed that those systems allow the compliance of discharge standards as well as the production of final effluents with suitability for reuse. Results obtained in a nine-month campaign in an HSSF bed pointed out that COD and TSS removal were lower than expected. A discrete sampling also showed that removal of TC, FC and HE was not enough to fulfill international irrigation goals. However, the bed had a very good response to variation of incoming nitrogen loads presenting high removal of nitrogen forms. A good correlation between mass load and mass removal rate was observed for $\mathrm{BOD}_{5}, \mathrm{COD}, \mathrm{TN}, \mathrm{NH}_{4}-\mathrm{N}$, TP and TSS, which shows a satisfactory response of the bed to the variable incoming loads. The entrance of excessive loads of organic matter and solids contributed for the decrease of the effective volume Department of Civil Engineering High Institute of Engineering of Lisbon (ISEL) R. Conselheiro Emídio Navarro, 1, 1950-062 Lisbon,

Portugal

E-mail: hmarecos@dec.isel.ipl.pt

António Albuquerque

C-MADE, Department of Civil Engineering and Architecture, University of Beira Interior,

Edificio 2 das Engenharias, Calcada Fonte do Lameiro, 6201-001 Covilha,

Portugal

E-mail:ajca@ubi.pt for pollutant uptake and therefore, may have negatively influenced the treatment capability. Primary treatment should be improved in order to decrease the variation of incoming organic and solid loads and to improve the removal of COD, solids and pathogenic. The final effluent presented good physical-chemical quality to be reused for irrigation, which is the most likely application in the area.
\end{abstract}

Key words | constructed wetlands, irrigation reuse, mass removal rates, treatment capability

\section{INTRODUCTION}

Although the provision of wastewater treatment plants (WWTP) is indispensable for water pollution control, in the light of the Water Framework Directive (2000/60/EC, WFD) and the recommendations of the World Water Assessment Programme (UNESCO 2009), the implementation of methodologies for integrated water management is strongly suggested. Solutions for low cost sewage treatment and selective reuse of treated effluents will constitute one of the great challenges in the water and sanitation sector over the next two decades.

Approximately $60 \%$ of the population of the Cova da Beira region lives in rural agglomerates with less than 2,000 inhabitants. The main activities are agriculture, tourism and small agro-industries. The WWTP are mostly based on doi: $10.2166 /$ wst.2010.063 constructed wetlands (CW) with horizontal subsurface flow (HSSF), which are sized based on international design criteria and experience (EPA I999; Kadlec et al. 2000; Vymazal 2003): 3 to $6 \mathrm{~m}^{2} /$ p.e. (as specific surface area, SSA), 2 to $12 \mathrm{gBOD}_{5} \mathrm{~m}^{-2} \mathrm{~d}^{-1}$ and 5 to $20 \mathrm{gCOD} / \mathrm{m}^{2} \mathrm{~d}$ (both as organic loading rate, OLR), 5 to $12 \mathrm{~g} \mathrm{TSS} / \mathrm{m}^{2} \mathrm{~d}$ (as solids loading rate, SLR), 2 to $20 \mathrm{~cm} / \mathrm{d}$ (as hydraulic loading rate, HLR) and 5 to $14 \mathrm{~d}$ (as hydraulic retention time, HRT). The German guideline ATV-A 262E (I998) suggests maximum allowable influent concentration of COD and TSS of $400 \mathrm{mg} / \mathrm{L}$ and $100 \mathrm{mg} / \mathrm{L}$, respectively, organic loading rate and solids loading rate not greater than $16 \mathrm{~g} \mathrm{COD} / \mathrm{m}^{2} \mathrm{~d}$ and $6 \mathrm{gTSS} / \mathrm{m}^{2} \mathrm{~d}$ respectively and a hydraulic loading rate lower than $4 \mathrm{~cm} / \mathrm{d}$, in order to minimize bed clogging. 
The Cova da Beira region is covered by an Irrigation Plan and there are several golf courses projects. Therefore, the mainly reuse opportunities would be for irrigation of public parks and lawns, landscape and golf courses, which often means offsetting potable water for non-potable purposes and maximizing the efficiency of reuse projects. However, these applications may require a polished effluent in terms of nutrients, organic matter and microorganism content. The selection of reuse options should be made based on a rational basis taking into account aspects such as variability of the quality over time, reuse guidelines and regulations, climate changes, technical requirements for WWTP upgrade and reuse projects cost-effectiveness.

Nutrients in treated wastewater may be valuable for crop production. However, pathogens are the most critical hazards to the public health, especially for options with direct contact with people. In addition to the socioeconomic benefit associated to multiple wastewater reuse activities an important environmental benefit comes from the reduction of residual pollutant load discharged into water streams, especially in areas with serious water shortage as the Beira Interior region.

CW are considered economically and environmentally sustainable solutions without entailing excessive operation and maintenance costs (Kadlec et al. 2000; Korkusuz 2005; Vymazal \& Kropfelova 2008). It is expectable that CW can fulfill the discharge standards set in the Urban Wastewater Treatment Directive (91/271/EEC) as well as the requirements for reuse established in several publications (EPA 2004; Bixio \& Wintgens 2006; Asano et al. 2007; Marecos do Monte \& Albuquerque 2009) and in the Portuguese standard NP 4434 (IPQ 2005). HSSF beds have been implemented in several wastewater reuse schemes worldwide as polishing step for conventional wastewater treatment (Ghermandi et al. 2007). Vymazal \& Kropfelova (2008) reported that $\mathrm{N}$ removal in most CW is low (up to $50 \%$ ) when compared to organics, solids and coliforms (up to $95 \%$ ). Most of the systems in the Cova da Beira region are located in areas with many small agro-industries and are subject to transient hydraulic, organic, nitrogen and solids loads (as observed by Albuquerque et al. 2009a), which may affect both the treatment capability and reuse options.

A research project (EVAWET) launched in 2007 aims to evaluate both the performance of HSSF beds located in small rural communities of Cova da Beira region and the suitability for reuse of the treated effluents. Therefore, the main objective of this paper is to present the results of a monitoring campaign undertaken in a HSSF bed and to analyse the bed performance for pollutant removal under transient conditions of hydraulic, organic, nitrogen and solid loads as well as the suitability of the treated effluent for irrigation reuse.

\section{EXPERIMENTS}

The monitored WWTP was designed for 800 p.e. The flow treatment includes a bar track and a sand channel followed by an Imhoff tank and two parallel HSSF beds. Each bed has $50 \times 15.5 \times 1 \mathrm{~m}$ (length, width and total depth), a total area of $773 \mathrm{~m}^{2}$ and was colonized with Phragmites australis. The media bed was composed of gravel $(0.95 \mathrm{~m})$ and the water during the monitoring period was $0.65 \mathrm{~m}$. The beds were designed for flow rates from 45 to $90 \mathrm{~m}^{3} / \mathrm{d}$, HLR from 7 to $15 \mathrm{~cm} / \mathrm{d}$, HRT from 4.5 to $9 \mathrm{~d}$, SSA from $2.5 \mathrm{~m}^{2} /$ p.e., $\mathrm{BOD}_{5}$ from 200 to $350 \mathrm{mg} / \mathrm{L}$ (maximum OLR of $15 \mathrm{gBOD}_{5} / \mathrm{m}^{2} \mathrm{~d}$ ) and COD from 300 to $500 \mathrm{mg} / \mathrm{L}$ (maximum OLR of $22 \mathrm{~g} \mathrm{COD} / \mathrm{m}^{2} \mathrm{~d}$ ).

A nine-month monitoring campaign was set up in one of the beds (March to December 2007) including the measurement of flow-rate (inflow and outflow of the bed) and the collection of monthly samples (a single sampling approximately at the same day and hour) at the influent and effluent of the bed to determine the $\mathrm{pH}$, temperature, dissolved oxygen (DO), $\mathrm{BOD}_{5}$, total and soluble COD (CODt and CODs), total nitrogen (TN), ammoniumnitrogen $\left(\mathrm{NH}_{4}-\mathrm{N}\right)$, nitrite-nitrogen $\left(\mathrm{NO}_{2}-\mathrm{N}\right)$, nitrate-nitrogen $\left(\mathrm{NO}_{3}-\mathrm{N}\right)$, total phosphorus (TP), total suspended solids (TSS), total dissolved solids (TDS) and volatile suspended solids (VSS). A discrete sampling (only one water sample at the influent and effluent) was made in order to have indicative values for parameters (total coliforms (TC), faecal coliforms (FC), helminth eggs (EH), chloride, bromates, calcium, potassium and sodium) that are reported by some authors (Metcalf \& Eddy 2003; Asano et al. 2007) for irrigation reuse.

The DO, pH and temperature were carried out directly using a multiparametric WTW Multi 340i. The CODt and 
CODs (after sample filtration with Chromafil GF/PET $0.45 \mu \mathrm{m}$ filters) were determined with cuvette tests LCK 314 (15-150 mg/L) and LCK 514 (100-2,000 mg/L), following DIN 38049-4, and a CADAS 50 Lange spectrometer. Ammonium and nitrate were obtained using the cuvette tests LCK $303(2-47 \mathrm{mg} / \mathrm{L})$ and LCK 339 (0.23-13.50 mg/L), following the standards DIN 38406-E 5-1 and DIN 38402-A51, TP with LCK $350(2-20 \mathrm{mg} / \mathrm{L})$ and the same spectrometer. TSS, TDS and VSS were determined according to APHA (I998). TC, FC, EH, chloride, bromates, calcium, potassium and sodium were analyzed in a external qualified laboratory following APHA (1998). The results were treated with the SPSS statistical software (SPSS Inc., Chicago, USA).

\section{$\overline{\text { RESULTS AND DISCUSSION }}$}

The results of the monitoring campaign are presented in Table 1. No nitrite was detected in the samples.

A statistical analysis on the results showed coefficients of variation $(\mathrm{CV})$ for $\mathrm{BOD}_{5}, \mathrm{COD}, \mathrm{TN}, \mathrm{NH}_{4}-\mathrm{N}$, TDS and TSS of $38 \%, 30 \%, 26 \%, 28 \%, 33 \%$ and $19 \%$ in the HSSF influent, indicating a significant fluctuation of its characteristics over time. The influent flow-rate showed also a

Table 1 | Operation conditions at the HSSF bed

\begin{tabular}{|c|c|c|}
\hline Parameter & Influent & Effluent \\
\hline Flow-rate $\left(\mathrm{m}^{3} / \mathrm{d}\right)$ & $35 \pm 4$ & $21 \pm 2$ \\
\hline $\mathrm{pH}$ & $6.4-7.0$ & $7.0-7.4$ \\
\hline Water temperature $\left({ }^{\circ} \mathrm{C}\right)$ & $19 \pm 2$ & $20 \pm 2$ \\
\hline $\mathrm{DO}(\mathrm{mg} / \mathrm{L})$ & $1.0 \pm 0.2$ & $1.2 \pm 0.3$ \\
\hline $\mathrm{BOD}_{5}(\mathrm{mg} / \mathrm{L})$ & $286 \pm 16$ & $15 \pm 4$ \\
\hline CODt $(\mathrm{mg} / \mathrm{L})$ & $344 \pm 44$ & $110 \pm 15$ \\
\hline CODs (mg/L) & $185 \pm 27$ & $38 \pm 16$ \\
\hline $\mathrm{TN}(\mathrm{mg} / \mathrm{L})$ & $38 \pm 5$ & $9 \pm 3$ \\
\hline $\mathrm{NH}_{4}-\mathrm{N}(\mathrm{mg} / \mathrm{L})$ & $33 \pm 3$ & $7 \pm 3$ \\
\hline $\mathrm{NO}_{3}-\mathrm{N}(\mathrm{mg} / \mathrm{L})$ & $1.5 \pm 0.6$ & $0.7 \pm 0.1$ \\
\hline $\mathrm{TP}(\mathrm{mg} / \mathrm{L})$ & $7 \pm 1$ & $3 \pm 1$ \\
\hline TSS (mg/L) & $116 \pm 20$ & $34 \pm 10$ \\
\hline TDS (mg/L) & $790 \pm 55$ & $225 \pm 23$ \\
\hline
\end{tabular}

Note: average values and confidence interval (calculated for a confidence level of $95 \%$ and 10 measured values). significant variation (CV of 45\%). Therefore, the Imhoff tank had no significant effect to stabilize the transient incoming loads.

The influent and effluent concentrations of $\mathrm{BOD}_{5}$ and COD were unstable over time with maximum values of $506 \mathrm{mg} \mathrm{BOD}_{5} / \mathrm{L}$ and $677 \mathrm{mgCOD} / \mathrm{L}$ (influent) and $187 \mathrm{mg} \mathrm{BOD}{ }_{5} / \mathrm{L}$ and $222 \mathrm{mg}$ COD/L (effluent). The average removal efficiencies were $94.8 \%$ for $\mathrm{BOD}_{5}$ and $68 \%$ for COD. A significant variation of the $\mathrm{TN}$ and $\mathrm{NH}_{4}-\mathrm{N}$ concentrations was also observed for the influent (highest values of $54.8 \mathrm{mg} / \mathrm{L}$ and $52.1 \mathrm{mg} / \mathrm{L}$, respectively) and final effluent (highest values of $16.8 \mathrm{mg} / \mathrm{L}$ and $13.6 \mathrm{mg} / \mathrm{L}$, respectively). The average removal efficiencies were $76.3 \%$ for $\mathrm{TN}$ and $78.8 \%$ for $\mathrm{NH}_{4}-\mathrm{N}$. TP average removal only reached $42.8 \%$, which is good for HSSF beds (Kadlec et al. 2000; Vymazal \& Kropfelova 2008).

The influent concentrations of TSS and TDS also changed significantly in the influent (highest values of $165 \mathrm{mg} / \mathrm{L}$ and $1,030 \mathrm{mg} / \mathrm{L}$, respectively) but the removal efficiency was quite similar $(70.7 \%$ for TSS and $71.5 \%$ for TDS). COD and TSS removal efficiencies were low compared with other studies (Table 2).

Generally, the final effluent presents characteristics which fulfill the limits set in the 91/271/EEC Directive. Only COD effluent concentrations exceeded the limit of the Directive $(125 \mathrm{mg} / \mathrm{L})$ in 2 samples. The bed was DO limited over time $(<2 \mathrm{mg} / \mathrm{L})$ which is characteristic of HSSF beds (EPA I999; Kadlec et al. 2000; Vymazal \& Kropfelova 2008; Albuquerque et al. 2009a). The high water temperature values are helpful for organic carbon and nitrogen removal since the kinetics are improved by temperature.

The physical-chemical results presented in Table 1 also show that the characteristics of the final effluent suggest his use for irrigation since it fulfills the goals set by several authors and organizations (Metcalf \& Eddy 2003; EPA 2004; Bixio \& Wintgens 2006; Asano et al. 2007; Marecos do Monte \& Albuquerque 2009): 6.5 to $8.4(\mathrm{pH}), 35$ to $60 \mathrm{mg} / \mathrm{L}$ (TSS), 450 to $640 \mathrm{mg} / \mathrm{L}$ (TDS), $5 \mathrm{mg} / \mathrm{L}\left(\mathrm{NO}_{3}-\mathrm{N}\right)$ and $3 \mathrm{mg} / \mathrm{L}$ (TP). However, data on microbiological quality is necessary before this suggestion may turn into a conclusion, because the analysis to the only water sample used for inorganic and pathogenic evaluation showed the following removal efficiencies: chloride (16.4\%), bromates (75\%), calcium 
Table 2 | Comparison of operating conditions and removal efficiencies in this study (a) and in other international similar systems ((b) to (e))

\begin{tabular}{|c|c|c|c|c|c|c|c|c|}
\hline \multicolumn{4}{|c|}{ Operating conditions } & \multicolumn{5}{|c|}{ Removal efficiency (\%) } \\
\hline OLR $\left(g \operatorname{COD} / \mathrm{m}^{2} \mathrm{~d}\right)$ & HLR $(\mathbf{c m} / \mathbf{d})$ & HRT (d) & SSA $\left(m^{2} /\right.$ p.e. $)$ & COD & TN & $\mathbf{N H}_{4}-\mathbf{N}$ & TSS & Reference \\
\hline $9.4-22.3$ & $8.5-13.8$ & $4.8-9$ & 2.5 & 68 & 76.3 & 78.8 & 70.7 & Portugal \\
\hline $26.4-52.7$ & $7.3-14.9$ & $2.5-5$ & - & 64.2 & - & 55.1 & 90.4 & Israel $^{\dagger}$ \\
\hline $2.2-34.1$ & $14.0-15.6$ & $3-4.3$ & 1.2 & 94 & 60 & 85 & 84 & Italy $^{\ddagger}$ \\
\hline $18.4-54.5$ & 18 & 3 & 1 & 43 & - & 25 & 73 & Spain $^{\S}$ \\
\hline 38.1 & 3.6 & 5 & 2.3 & 78 & 35 & 22.6 & 78 & Egypt $^{\|}$ \\
\hline
\end{tabular}

*This study case.

${ }^{\dagger}$ Avsara et al. (2007).

${ }^{\ddagger}$ Masi \& Martinuzzib (2007).

§Osorio (2006).

"El-Khateeb \& El-Gohary (2003).

(no removal), potassium (18.2\%), sodium (15.8\%), TC (72.2\%), FC (80.4\%) and EH (16.7\%). The effluent concentrations of inorganic parameters are below the limits set for irrigation by Metcalf \& Eddy (2003), EPA (2004) and Asano et al. (2007). However, the values of TC $\left(1 \times 10^{6} \mathrm{NMP} /\right.$ $100 \mathrm{~mL})$, TC $\left(5.5 \times 10^{5} \mathrm{NMP} / 100 \mathrm{~mL}\right)$ and HE $(120 \mathrm{NMP} /$ $100 \mathrm{~mL}$ ) at the effluent are high and a final disinfection would be required prior to its use in irrigation.

It seems that there is a relationship between the low removal of COD and the low removal of TSS and TDS. Approximately $46 \%$ of the HSSF influent CODt was in particulate phase while $65.4 \%$ was observed in the effluent, which indicates that a considerable amount of slowly biodegradable organic matter and inert matter, mainly as TSS, were not removed in the wetland bed (only 54.7\% of the CODp was removed whilst the removal of CODt and CODs was $68 \%$ and $79.5 \%$, respectively). The ratio of VSS/TSS in the HSSF effluent was equal to 0.48 , which could indicate a low degree of effluent mineralization and the presence of considerable organic matter content. The occurrence of a large amount of particulate hardly degradable organic matter is probably due to significant discharge of agro-industrial effluents into the sewer network as also observed by Albuquerque et al. (2009a) in a shorter monitoring campaign carried out in the same region. The low removal of TDS also means that a significant content of slowly biodegradable soluble organic matter was present in the effluent.

Although a significant variability of $\mathrm{TN}$ and $\mathrm{NH}_{4}-\mathrm{N}$ over time was observed in the inlet, the removal efficiency of both nitrogen forms was higher than the ones observed in international studies with HSSF bed operated in comparable conditions (Table 2). The effluent concentrations of TN were always below the limit set for discharge in the 91/271/EEC Directive (15 mg/L) and the bed outperformed the minimum removal efficiency required (70\%).

The bed also gave a good response to nitrate fluctuations. Given the high ammonia removal in the bed and the DO limitation to carry out full nitrification it can be speculate that other mechanisms would have contributed for ammonia removal, namely plant uptake (can remove up to 20\%, Vymazal 2003; Vymazal \& Kropfelova 2008), sedimentation and filtration and non-conventional removal pathways as referred by Paredes et al. (2007) and observed in the studies of Dong \& Sun (2007) and Albuquerque et al. (2009b). However, most of them must have been oxidized to nitrate and the low concentration detected in the final effluent may indicate that this compound was rapidly removed through mechanisms such as denitrification.

The areal mass removal rates (in $\mathrm{g} / \mathrm{m}^{2} \mathrm{~d}$ ) were calculated for $\mathrm{BOD}_{5}, \mathrm{COD}, \mathrm{TN}, \mathrm{NH}_{4}-\mathrm{N}, \mathrm{TP}$, TDS and TSS based on the influent and effluent concentrations, the influent and effluent flow rates and the total area of the bed. A significant linear correlation was observed between incoming mass load and the respective mass removal rates $\left(r_{\left(\mathrm{BOD}_{5}\right)}, r_{(\mathrm{COD})}, r_{(\mathrm{TN})}, r_{\left(\mathrm{NH}_{4}-\mathrm{N}\right)}, r_{(\mathrm{TP})}, r_{(\mathrm{TSS})}\right.$ and $\left.r_{(\mathrm{TDS})}\right)$ for six parameters, in particular for $\mathrm{BOD}_{5}\left(R^{2}=0.99\right)$, COD $\left(R^{2}=0.92\right)$, TN $\left(R^{2}=0.74\right)$ and $\mathrm{NH}_{4}-\mathrm{N}\left(R^{2}=0.67\right)$ as shown in Figure 1.

The average $r_{(\mathrm{COD})} \quad\left(10 \mathrm{gCOD} / \mathrm{m}^{2} \mathrm{~d}\right)$ and $r_{(\mathrm{TSS})}$ $\left(4.1 \mathrm{~g} \mathrm{TSS} / \mathrm{m}^{2} \mathrm{~d}\right)$ found in this study are lower than the 

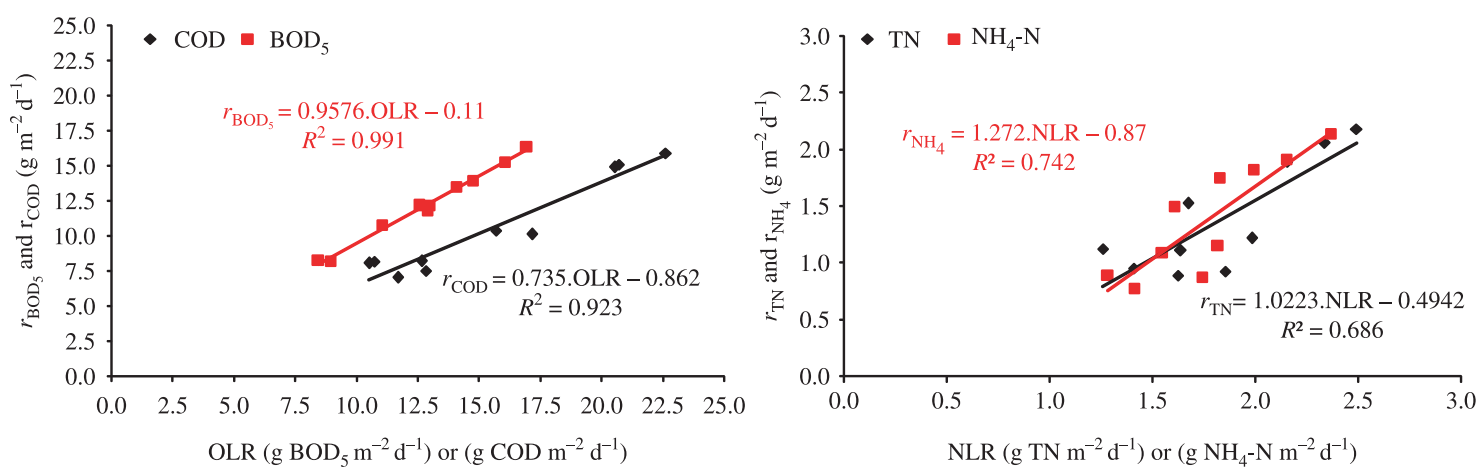

Figure 1 Relationship between OLR and $r_{\left(\mathrm{BOD}_{5}\right)}$ and $r_{(\mathrm{COD})}$ (a) and between NLR and $r_{(\mathrm{TN})}$ and $r_{\left(\mathrm{NH}_{4}-\mathrm{N}\right)}$ (b).

ones observed in similar systems in other countries: $17.1 \mathrm{~g}$ $\mathrm{COD} / \mathrm{m}^{2} \mathrm{~d}$ and $7.9 \mathrm{gTSS} / \mathrm{m}^{2} \mathrm{~d}$ (Avsara et al. 2007), $23.7 \mathrm{~g} \mathrm{COD} / \mathrm{m}^{2} \mathrm{~d}$ and $7.8 \mathrm{gTSS} / \mathrm{m}^{2} \mathrm{~d}$ (Osorio 2006), and $20.4 \mathrm{gCOD} / \mathrm{m}^{2} \mathrm{~d}$ and $6.4 \mathrm{gTSS} / \mathrm{m}^{2} \mathrm{~d}$ (El-Khateeb \& El-Gohary 2003). However, they are still in the range of the world-wide experience $\left(10-25 \mathrm{gCOD} / \mathrm{m}^{2} \mathrm{~d}\right.$ and $0.5-10 \mathrm{~g} \mathrm{TSS} / \mathrm{m}^{2} \mathrm{~d}$ according to EPA (1999), Kadlec et al. (2000), Vymazal (2003) and Korkusuz (2005)). The lower values are associated to the presence of large amount of particulate organic matter in the influent to the HSSF bed.

Although the HSSF bed presents a SSA and a HRT similar to values found in similar systems (Table 2), it seems that they were not sufficient for a good COD removal due to the transient incoming organic loads. The observed HLR, HRT, OLR and average COD were in the range of the design criteria used to size the bed, however, there were detected peaks of COD higher than $500 \mathrm{mg} / \mathrm{L}$ (higher value than the considered in the wetland bed design), which increase the risk of bed clogging. Nevertheless, during the warmer months (June to September) the results showed that the SSA of $2.5 \mathrm{~m}^{2} /$ p.e. seems to have been sufficient to comply with the minimum treatment requirements. In other words, the HSSF bed itself seems to have been properly sized for the loads admitted in the project design but the previous treatment appears to not be appropriate to deal with transient loads (especially of organic matter and solids).

Some ponding was observed in the bed, mainly at the inlet corners, which would mean the occurrence of clogging as a result of the variability of the wastewater characteristics and the excess of suspended solid matter as also observed by Albuquerque et al. (2009a). The applied
OLR (9.4 to $22.3 \mathrm{gCOD} / \mathrm{m}^{2} \mathrm{~d}$ ) is higher than the values suggested in the literature ( 5 to $20 \mathrm{gCOD} / \mathrm{m}^{2} \mathrm{~d}$ ), as well as to the limit value for avoiding bed clogging pointed out in the Germany standard ATV-A 262E (1998) (less than $16 \mathrm{~g} \mathrm{COD} / \mathrm{m}^{2} \mathrm{~d}$ ). Although the average solids loading rate $\left(4.2 \mathrm{~g} \mathrm{TSS} / \mathrm{m}^{2} \mathrm{~d}\right)$ was lower than the one recommended for avoiding bed clogging $\left(6 \mathrm{gTSS} / \mathrm{m}^{2} \mathrm{~d}\right.$, according to ATV-A 262E (I998) and EPA (I999)), the average influent concentration of TSS $(118.6 \mathrm{mg} / \mathrm{L})$ was greater than the maximum suggested for clogging prevention by both authors $(100 \mathrm{mg} / \mathrm{L})$.

The clogged areas of the bed close the entrance may be a factor contributing for the decrease of TSS and COD removals since the effective area for organic matter uptake and the filterability capability were reduced. Therefore, HSSF beds subject to transient high loads should be designed for higher OLR and SLR and the inclusion of advanced primary treatment systems (e.g. filter screens or high-rate clarification) should be considered, in order to reduce the amount of CODp and TSS to the beds. This change would also improved the removal efficiency of pathogenic since will allow a larger area for filtration.

The final characteristics of the treated effluent (Table 1) allow its reuse in irrigation activities (EPA 2004; Bixio \& Wintgens 2006; Asano et al. 2007; Marecos do Monte \& Albuquerque 2009), particularly for the irrigation of crop cultures and golf courses in Cova da Beira. The content of organic matter and nutrients of the effluent is proper for irrigation in those activities, although it is necessary to include additional analysis of turbidity and heavy metals and to increase the sampling for cations (chloride, bromates, calcium, potassium and sodium) and microbiological 
parameters (TC, FC, EH), especially if irrigation of agricultural crops for direct consumption is considered. The low nitrate concentrations detected in the effluent $(<5 \mathrm{mg} / \mathrm{L})$, in contrast to what is observed in other treatment systems, is suitable for irrigation and constitutes a very low risk for groundwater contamination.

The reuse of treated effluents from HSSF CW may brings important advantages such as the production of water suitable for irrigation, the reduction of residual pollution loads discharged in water streams and the reduction of water abstraction volumes for irrigation, which constitute important environmental and economics benefits, especially in areas with serious water shortage as the Beira Interior region.

Accordingly, the use of $\mathrm{CW}$ for wastewater treatment in rural areas of Cova da Beira seems to be a very advantageous practice for both the removal of transient pollutant loads and the production of final effluents for irrigation, which are in accordance with the objectives for water quality protection defined in the WFD.

\section{CONCLUSIONS}

The results of the monitoring campaign highlight that the HSSF constructed wetland of the Cova da Beira region can effectively represent a feasible solution for simultaneous secondary/tertiary treatment of rural effluents with significant fluctuations in incoming flow rate, organic mater, nitrogen and solid mater. The removal of COD and TSS were lower than the values observed in other similar studies, which was associated to partial bed clogging together with the presence of a large amount of particulate organic matter. The bed had a very good performance in terms of $\mathrm{TP}, \mathrm{TN}, \mathrm{NH}_{4}-\mathrm{N}$ and $\mathrm{NO}_{3}-\mathrm{N}$, despite the variation of the incoming concentrations, presenting removal rates in the range of the values found in similar studies. The only available set of TC, FC and $\mathrm{EH}$ analysis indicated that the bed had a low performance in terms of pathogenic removal but more analysis are needed in order to stress a deeply analysis. A good correlation was observed between mass removal rates and mass loads $\mathrm{BOD}_{5}, \mathrm{COD}, \mathrm{TN}, \mathrm{NH}_{4}-\mathrm{N}$, TP and TSS, which clarifies that the HSSF bed had a satisfactory response to changes in incoming loads.
The SSA of the HSSF bed seems to be sufficient for loads similar to the ones admitted in the design. However, the prelimary and primary treatments should be improved in order to face the transient loads of organic matter and solids. As a precaution measure, HSSF beds subject to transient high loads should be designed for higher OLR and SLR than the ones suggests in literature. Results show that the physical-chemical quality of the effluent of this $\mathrm{CW}$ is suitable for reuse in agricultural and landscape irrigation. $\mathrm{pH}, \mathrm{COD}$, TSS, TDS, TN and nitrate are within the values recommended by national and international studies.

\section{ACKNOWLEDGEMENTS}

The authors wish to thank the Portuguese Foundation for Science and Technology, which funded the work through the project PTDC/AMB/73081/2006 as well as the support provided by the water authority Aguas do Zezere e Coa SA.

\section{REFERENCES}

Albuquerque, A., Arendacz, M., Gajewska, M., ObarskaPempkowiak, H., Randerson, P. \& Kowalik, P. 2009a Removal of organic matter and nitrogen in a HSSF constructed wetland under transient loads. Water Sci. Technol. 60(7), 1677-1682.

Albuquerque, A., Oliveira, J., Semitela, S. \& Amaral, L. $2009 b$ Influence of bed media characteristics on ammonia and nitrate removal in shallow horizontal subsurface flow constructed wetlands. Bioresour. Technol. 100, 6269-6277.

APHA 1998 Standard Methods for the Examination of Water and Wastewater. 20th edition, American Public Health Association/American Water Works Association/Water Environment Federation, Washington DC, USA.

Asano, T., Burton, F., Leverenz, H., Tsuchihashi, R. E. \& Tchobanoglous, G. 2007 Water Reuse. McGrawHill, New York, USA.

ATV-A 262E 1998 Principles for the dimensioning, construction and operation of plant beds for communal wastewater with capacities up to 1000 total number of inhabitants and population equivalents. DWA, Hennef, Germany.

Avsara, Y., Tarabeahb, H., Kimchiec, S. \& Ozturkd, I. 2007 Rehabilitation by constructed wetlands of available wastewater treatment plant in Sakhnin. Ecol. Eng. 29, 27-32.

Bixio, D. \& Wintgens, T. 2006 Water reuse system managementManual AQUAREC. Directorate-General for Research, European Comission Brussels, Belgium. 
Dong, Z. \& Sun, T. 2007 A potential new process for improving nitrogen removal in constructed wetlands-promoting coexistence of partial-nitrification and ANAMMOX. Ecol. Eng. 31, 69-78.

El-Khateeb, M. \& El-Gohary, F. 2003 Combining UASB technology and constructed wetland for domestic wastewater reclamation and reuse. Water Sci. Technol.: Water Supply 3(4), 201-208.

EPA 1999 Constructed Wetlands Treatment of Municipal Wastewaters. EPA/625/R-99/010, Cincinnati, Ohio, USA.

EPA 2004 Guidelines for Water Reuse. Report EPA/625/R-04/108, Environmental Protection Agency, Washington, USA.

Ghermandi, A., Bixio, D. \& Thoeye, C. 2007 The role of free water surface constructed wetlands as polishing step in municipal wastewater reclamation and reuse. Sci. Total Environ. $380(1-3), 247-258$.

IPQ-NP 4434:2005 2005 Reuse of Treated Wastewater in Agriculture. Portuguese standard, Instituto Português da Qualidade, Caparica, Portugal. (in Portuguese).

Kadlec, R., Knight, R., Vymazal, J., Brix, H., Cooper, P. \& Haberl, R. 2000 Constructed Wetlands for Pollution Control: Processes, Performance, Design and Operation. Report No. 8, IWA Publishing, London, UK.

Korkusuz, E. A. 2005 Manual of Practice on Constructed Wetlands for Wastewater Treatment and Reuse in Mediterranean Countries. Report AVKR 5, MED-REUNET, Crete, Greece.
Marecos do Monte, M. H. \& Albuquerque, A. 2009 Wastewater Reuse. Technical Guide 11, IRAR, Lisbon, Portugal, p. 363. (in Portuguese).

Masi, F. \& Martinuzzib, N. 2007 Constructed wetlands for the Mediterranean countries: hybrid systems for water reuse and sustainable sanitation. Desalination 215, 44-55.

Metcalf \& Eddy, Inc., 2003 Wastewater Engineering: Treatment and Reuse (4th edn), McGraw-Hill, New York, USA

Osorio, A. 2006 Influence of the characteristics of organic matter on the efficiency of HSSF constructed wetlands. PhD thesis, Univ. Politecnica Cataluna, Barcelona, Spain.

Paredes, D., Kuschk, P., Mbwette, T., Stange, F., Muller, R. \& Koser, H. 2007 New aspects of microbial nitrogen transformations in the context of wastewater treatment-a review. Eng. Life Sci. 7(1), 13-25.

UNESCO 2009 Water in a changing world (WWDR-3). 3rd United Nations World Water Development Report, UNESCO, Butler, Tanner \& Dennis, UK. p. 320.

Vymazal, J. 2003 Types of constructed wetlands. In Proc. Int. Seminar on the Use of Aquatic Macrophytes for Wastewater Treatment in Constructed Wetlands. Lisbon, Portugal, May 8-10, pp. 35-79.

Vymazal, J. \& Kropfelova, L. 2008 Wastewater Treatment in Constructed Wetlands with Horizontal Sub-Surface Flow. Series of Env. Pollution 14, Springer, Germany, p. 566. 